\title{
Suitability of commercial transport for a shift to electric mobility with Denmark and Germany as use cases
}

\author{
Linda Christensen a , Jens Klauenberg ${ }^{\text {b, }}$, Ole Kveiborg ${ }^{c}$, Christian Rudolph ${ }^{\text {b }}$ \\ a Technical University of Denmark, Department of Management Engineering, Bygningstorvet 116V, 2800 Lyngby, Denmark \\ ${ }^{\mathrm{b}}$ German Aerospace Center, Institute of Transport Research, Rutherfordstrasse 2, 12489 Berlin, Germany \\ ${ }^{\text {c } C O W I}$ A/S, Parallelvej 2, 2800 Kongens Lyngby, Denmark
}

\section{A R T I C L E I N F O}

\section{Article history:}

Received 17 December 2015

Received in revised form

1 July 2016

Accepted 14 September 2016

Available online 28 September 2017

\section{JEL classification:}

D78

E61

G38

L91

R42

Keywords:

Commercial transport

Electric mobility

Light duty vehicles

Urban freight

Driving licence regulation

\begin{abstract}
A B S T R A C T
This paper identifies commercial sectors suitable for a shift to electric mobility in Denmark and Germany by analysing daily driving distance. The paper concludes that construction, human health and other service sectors are the most suitable sectors for electric mobility because many vehicles are registered in these sectors and daily mileage is reasonably low. They should be primary target groups of specific policy measures to promote the use of electric vehicles.

Both Denmark and Germany have incentives to promote the use of electric vehicles. Nevertheless, electric vehicles do generally not show economic benefits unless travel distance is high. However, today the travel range of large vans is an important barrier for electrification due to battery weight and the limitation of 3.5 tonnes gross vehicle weight for driving with a normal driving licence. The rule needs amendments for electric vehicles, as has been done in Germany. The paper recommends EU countries follow the German rule allowing EVs up to 4.25 tonnes to be driven with a class B licence, thereby potentially creating a market for big vans with long travel range.
\end{abstract}

() 2017 Elsevier Ltd. All rights reserved.

\section{Introduction}

To promote the application of a more sustainable and cleaner freight transport, the use of electric vehicles (EVs) may be an attractive solution to improve air quality in the city centre, reduce $\mathrm{CO}_{2}$ emissions, and reduce noise nuisance (Kemp, Truffer, \& Harms, 2000; Van Duin, Tavasszy, \& Quak, 2013). Until now, mainly private electric passenger cars have been studied. However, in recent years the use of EVs has begun to spread to other transport sectors as well. But while global retail and delivery companies have started to consider using alternatively fuelled vehicles, only a marginal share of the fleet has been studied so far (Bae, Sarkis, \& Yoo, 2011). In recent years, several research projects have been carried out regarding user needs (COMPETT Team, 2015; Evans \& Azmin-

\footnotetext{
* Corresponding author.

E-mail addresses: lch@Transport.dtu.dk (L. Christensen), jens.klauenberg@dlr.de (J. Klauenberg), olek@cowi.dk (O. Kveiborg), christian.rudoplh@dlr.de (C. Rudolph).
}

Fouladi, 2005; Hoogma, 2002), user acceptance (Globisch, Schneider, \& Dütschke, 2013; Green eMotion Team, 2015; Kasten, Zimmer, \& Leppler, 2011; Kreiner, Maringer, \& Zechner, 2011; Trommer, Jarass, \& Kolarova, 2015) and identification of mobility patterns in relation to electric vehicles (Bühler, Franke, \& Krems, 2011; Franke, Bühler, Cocron, Neumann, \& Krems, 2012; Hackbarth, Lunz, Madlener, Sauer, \& De Doncker, 2010; Hanke, Hülsmann, \& Fornahl, 2014; Reiner, Cartalos, Evrigenis, \& Viljamaa, 2010; Schuller \& Hoeffer, 2014; Scott, Hopkins, \& Stephenson, 2014). However, most projects focus on private users and electric passenger cars, even though most EVs are registered as company cars (Mock \& Yang, 2014). Especially due to the lack of electrified light duty vehicles, little is known regarding the use of electric vehicles for commercial transport, i.e. transport of goods and service delivery. But research into the potentials for passenger EVs in commercial applications is widely neglected, too.

Several requirements need to be fulfilled for a company to replace their conventional cars with EVs. Firstly, the transport requirements and expectations expressed by drivers and/or operators 
have to be met. This is clearly demonstrated by an evaluation of the Swedish electric vehicle procurement trial for commercial fleets in 2010-12 (Wikström, 2015; Wikström, Hansson, \& Alvfors, 2015, 2014). The study is the most comprehensive study in Europe known to the authors focusing on commercial use of EVs. Secondly, the EV has to be economically feasible or even more attractive than a conventional vehicle (Bae et al., 2011; COWI, 2014; Feng \& Figliozzi, 2013). Thirdly, the vehicle needs to be accepted by the owner and/or the vehicle manager (Kaplan, Gruber, Reinthaler, \& Klauenberg, 2016).

\subsection{Policy to support development in the commercial EV market}

There are attempts to support the deployment of EVs in European countries, but only few of them focus on commercial vehicle usage. In Denmark EVs were exempted from purchase tax and annual user tax from 2009 to 2015 . This exemption is actually being phased out and disappear from 2020 onwards (Skatteministeriet, 2015c). As only passenger cars and small vans pay purchase tax, this exemption has mainly had an effect on the price of passenger cars. Furthermore, power suppliers can deliver electricity for free to companies when dedicated to mobility. During 2008 to 2015, the Danish government set up different EV programmes mainly dedicated companies to support the introduction of EVs and the development of a charging infrastructure with an overall budget of EUR 12 million (Energistyrelsen, 2015a). The programme has resulted in an increasing network of fast charging stations and local low-power chargers. Free parking in city centres has been brought in by local initiatives and is now included in Danish legislation. In Denmark no economic initiatives specifically dedicated to commercial EVs have been taken.

In Germany, four ministries promoted electric vehicles in a plan to develop the country as a leading electric mobility market (Bundesministerium für Wirtschaft und Energie, 2009). A goal of one million electric vehicles by 2020 was set in 2009 (Die Bundesregierung, 2009). One of the first main steps was the funding of eight model regions. The governmental support programme was in 2011 followed up by six regional show cases (Dudenhöffer, Bussmann, \& Dudenhöffer, 2012). The Electric Mobility Promotion Act was ratified in 2014 (Deutscher Bundestag, 2014). Since 2011 electric vehicles and plug-in hybrids have been exempted from the annual vehicle tax for five years, whereas no policy measures reduce the purchase price. A special focus is applied to commercial vehicles, because a substantial market growth can be reached in commercial fleets with relatively modest financial support (Gnann, Plötz, Kühn, \& Wietschel, 2015). In the beginning of 2016 the German government revealed plans to subsidise the purchase of EVs and to expand the EV charging infrastructure. Especially more public fast charging stations shall be installed (Die Bundesregierung, 2016).

Even though a growing number of EVs have been observed in recent years, numbers are far from the ambitious 2008 goal. By the end of 2015 only 25,502 BEVs (battery electric vehicles) were registered in Germany and 8000 EVs in Denmark (Dansk Elbil Alliance, 2015).

The number of EVs per capita is smaller than, for example, in Sweden (whose 10,000 commercial vehicles represent a substantial share (Wikström, 2015)) and especially smaller than in Norway $(50,000$ (Figenbaum et al., 2015)), in which both substantial economic incentives and other initiatives favouring EVs are in use, but no policies are dedicated to commercial vehicles. Holtsmark and Skonhoft (2014) are questioning the economic feasibility of the unusually high economic support.

\subsection{The purpose of the paper}

The overall purpose of the paper is to demonstrate possibilities to reduce the climate burden from commercial transport by shifting from combustion engines to electric drive with BEVs. The more vehicle kilometres (sum of annual kilometres driven by all vehicles) that can be shifted to electric drive, the higher is the potential for reducing the climate burden, especially when the power supply is converted to renewable energy. A shift from combustion engines to electric drive furthermore reduces local air pollution and noise, which are important problems in urban areas with high concentrations of people in the streets and residences along the roadsides. The aim of this study could also have been to reduce the burden on urban areas from commercial transport. However, as the main contribution of the work is focused on available statistical information about number of vehicles and vehicle kilometres, no knowledge is available about the areas where the vehicles are driving.

The purpose can be achieved by shifting to electric drive for a high number of vehicles and/or by a shift for vehicles driving many kilometres. As the driving range of BEVs is limited, the goal can only be obtained by replacing as many conventional vehicles as possible with BEVs.

The method of the present paper is to identify which economic sectors a) have a high share of commercial vehicles on the one hand, and b) are most suited for changing to electric drive due to their daily driving pattern. By focusing on these two parameters it should be possible to find the most cost-effective targets for potential policy measures and business cases for electric vehicles. This paper presents the results of statistical analyses of the commercial transport sector in Denmark and Germany, enriched in a third step with more detailed analyses based on GPS tracking. The analyses show to which extent vehicles in the different economic sectors have a driving pattern making it possible to replace the existing conventional vehicles with electric vehicles.

Compared to private mobility, the transport needs of the commercial transport sector are much more diverse. Usage patterns are subject to customer requirements, financial and organisational conditions or restrictions (Hebes, Menge, \& Lenz, 2010). However, there is no general pattern; rather, each economic sector and subsector may have its own particular way of organising its mobility. Nevertheless, transport surveys show that driving patterns in some business branches are more suitable for the application of EVs than others. Thus target-group-specific policies for the promotion of electric mobility might be attractive. Christensen (2011), for instance, shows that for Denmark around $80 \%$ of vans and $70 \%$ of small lorries are driven less than $150 \mathrm{~km}$ per working day. Some sectors have highly identical uses of their vehicles over a long period, as is the case within the Swedish procurement programme, for example (Wikström et al., 2015), whereas in other sectors the daily driven distance may vary strongly from day to day, e.g. in the service sector.

A detailed picture of the variety of potential users and their requirements is necessary to assess the market potential for EVs and to develop adequate policy instruments to facilitate their introduction.

In this paper we analyse different business sectors in detail to enable national and local politicians to design stimulus programmes targeting the most suitable groups for a shift to EVs at the current state of technological development. The results are also valuable for the automotive industry to know for which business sectors EVs should be designed.

Using the two countries Denmark and Germany as show cases is interesting due to their very different policy regulation and taxation of vehicles in general and of commercial vehicles specifically. 
This makes it possible to identify to great effect how policies impact the structure of the commercial fleet across countries with rather different taxing structures.

\section{Methodology}

\subsection{Assessment of the potential for EVs per economic sector}

In order to assess the potential for EVs of each economic sector, three analyses were conducted for both Germany and Denmark:

Firstly is presented an overview of the size of the commercial vehicle stock as distributed across economic sectors, enabling us to identify which sectors have a high number of vehicles, and thus where the potential for the largest number of EVs may exist. The following sections will mainly focus on these sectors.

Next, the distributions of the average daily travel distances are analysed for passenger cars with commercial owner, light duty vehicles (LDV) with a gross vehicle weight (GVW) up to 3.5 tonnes and lorries with a GVW of up to 12 tonnes for all economic sectors according to the statistical classification of economic activities in the European Community (NACE, see European Commission, 2015). Only these three vehicle segments are analysed as there are virtually no electrified heavy trucks available on the market. The objective is to uncover the variation in average in travel distance of vehicles of different sizes and sectors, and to discuss these in relation to the possible range of commercial EVs. The daily travel distance is important when assessing if the vehicles can be driven a full working day without being charged. The average length of pauses between trip sections are also analysed in the case of Germany, to show if it might be possible to charge during the day. In this way it is possible to assess the share of the stock in each sector that will technically be suitable for shifting from conventional to electric vehicles, dependent on travel range.

Finally, in order to check the robustness of the results and the applicability of EVs, we will analyse the daily variation in mileage of the vehicles in selected companies of some of the most promising economic sectors by GPS-logging. In daily life it is necessary for the EV owner to be able to drive every day without spending time charging unless it can be done simultaneously with other duties. An average travel distance per day calculated over one or more years does not show how many days the permissible mileage of the EV would be exceeded and therefore it is necessary to assess the daily driving pattern.

\subsection{Criteria: maximum driving range}

A limiting criterion of EVs is the maximum daily mileage for vehicles. It is therefore needed to decide a threshold of the daily driving range we could measure against. The maximum driving range of most of the passenger EVs presently on the market varies between 130 and $200 \mathrm{~km}$ according to the manufacturers. An exception is the luxury and expensive passenger cars from Tesla Motors with a maximum range up to $500 \mathrm{~km}$. The maximum mileage of LDVs, according to the manufacturers, varies between 100 and $170 \mathrm{~km}$.

However, in practise the travel range is not as long as promised by the test driving circles, according to results from the Danish support programme financed by the Energy Department (Energistyrelsen, 2015b). The travel range depends on the individual driving behaviour related to speed, acceleration and breaking (Duke, Andrews, \& Anderson, 2009; Energistyrelsen, 2015b; Fetene, Prato, Kaplan, Mabit, \& Jensen, 2015; Greaves, Backman, \& Ellison, 2014). Furthermore, the driving range is reduced due to outdoor temperature (use of heating, air conditioning etc.) (Fetene et al., 2015), topography of the area and transported weight (number of passengers, weight of goods etc., size of car). By using the energy consumption model developed by Fetene et al. (2015) on GPS tracking of conventional vehicles, both passenger cars and vans, driving during summer and winter periods the average driving range is derived in a Danish environment (Barfod, Kaplan, Frenzel, \& Klauenberg, 2016). The resulting average driving range is $158 \mathrm{~km}$ during a summer period and $115 \mathrm{~km}$ during a winter period for passenger cars like Nissan Leaf, E-Golf and Mercedes B, which have an official driving range of $200 \mathrm{~km}$. For the Nissan e-NV200 van, with an official range of $170 \mathrm{~km}$ when fully charged, the travel range in real traffic during a summer period is only $111 \mathrm{~km}$. For all cars it is assumed that the drivers drive the car in the same way as they drive a conventional car.

Next, range anxiety has to be considered (Wikström, Hansson, \& Alvfors, 2014) show that employees who can choose between electric and conventional vehicles from a fleet with both kinds of vehicles generally choose a conventional vehicle if the expected distance to drive during the specific day might be more than approximately $70 \mathrm{~km}$. When a vehicle is assigned to only one user, the user tends to choose a conventional car when a proper introduction on how to use EVs was not given initially. Especially in these situations, a daily mileage of up to $100 \mathrm{~km}$ puts stress on the users. In Swedish winter periods the EVs are used rather little and use was not higher during the second year of the trial, indicating that fleet drivers who have a choice are no more confident with the travel range and avoid EVs in cold weather (Sun, Yamamoto, \& Morikawa, 2015) show, based on studies of mid trip charging by Japanese EV drivers, that a commercial EV during a working day will require $3.6-5.2 \mathrm{kWh}$ as a minimum power left when charging. The level probably depends on sector and type of trip, but the observation is not further explained. With a $24 \mathrm{kWh}$ battery, this equals $15-20 \%$ of the capacity, which under average conditions reduces the above-mentioned travel ranges to $125-135 \mathrm{~km}$ for passenger cars in summer and to $92-98 \mathrm{~km}$ during the winter. For the LDV with the lower official travel range, the practical travel range will only be $88-94 \mathrm{~km}$ in a summer period.

Recharging during the day can extend the daily travel range. However, recharging may take several hours. When considering loss in the converter, a normal electric outlet allowing 10 Amp only delivers $2.1 \mathrm{kWh}$ per hour (Christensen, 2011). Using fast charging a substantial recharge can be performed within 20-30 min (up to $80 \%$ of the battery capacity), but fast charging facilities are scarce and normally not available where commercial vehicles need them (Wikström et al., 2015) therefore show that recharging is only very seldom applied by commercial EV users.

All together as an outset for the analyses two thresholds are applied:

- $50 \mathrm{~km}$ maximum driving range without recharging: Vehicles driving less than $50 \mathrm{~km}$ per day is deemed to be suitable for electric mobility in any case.

- $100 \mathrm{~km}$ maximum driving range without recharging: Most of the electric passenger cars and small vans are able to be driven up to $100 \mathrm{~km}$ even though they, with current technology, need to adapt their driving pattern in winter time. For an LDV with a GVW of 3.5 tonnes or more, this travel range can only be achieved with new models of LDVs with bigger battery capacity or next generations of electric LDVs.

\subsection{Data for statistical analyses in section 3.1 and 3.2}

Data sources for Section 3.1 are for both countries the Central Vehicle Register. For Germany it is found in publications and statistical data from the German Federal Motor Transport Authority 
(KBA). For Denmark information is found in a dataset in a closed environment at Statistics Denmark.

The statistical analysis in Section 3.2.2 of commercial transport in Denmark is based on a dataset with the results of odometer readings during mandatory vehicle inspections from 2007 to 2012 (called SynsData) maintained by Statistics Denmark. The inspection of passenger cars is made no later than 4 years after first registration date and every second year afterwards. For vans and LDVs it is made two years after first registration and once a year afterwards. SynsData is supplemented with data from other public registers in a closed computer environment at Statistics Denmark with access to the full databases with all vehicles. The calculations are run the following way:

1. From SynsData information is extracted about the date and mileage at each inspection, the owner (listed by a code for privacy), the number plate, type and GVW. The mileage between each inspection is calculated and divided by the number of days between two inspections.

2. The calculated mileage per day for periods before 2006 and from periods where the ownership was changed between the two readings is removed. Only data for vehicles with commercial owners are kept.

3. This dataset is merged with annual extracts from the Motor Register by the number plate. The company registration number by January 1 st is extracted and kept.

4. This dataset is merged with a register with account data for firms and with a register of employees by the company registration number. The NACE code for the economic sector and a detailed branch code are extracted. Unfortunately, the project did not have access to the full company register with branch codes for all companies. The NACE and branch codes are missing for companies without employees or with an annual turnover under EUR 40,000.

The daily mileage as extracted from SynsData is, as suggested in Christensen (2011), recalculated to kilometres per working day, assumed to be 225 days per year on average ( 5 days a week and 45 weeks per year; vacations and public holidays this way being excluded). The number of travelling days might be higher for lorries and fleet vehicles used by several employees and therefore driving during holiday seasons and weekends, too. However, by using 225 days to calculate the daily average travel distance, we are more on the safe side and do not underestimate the daily mileage.

The data source for the German statistical analysis in section 3.2.1 is the empirical survey data from Motor Vehicle Traffic in Germany KiD 2010 (Wermuth, Neef, Hautzinger, Lenz, \& Heinzmann, 2012) which is a nationwide representative survey of vehicle owners on the usage of motor vehicles conducted through one year. The number of observation in KiD 2010 is 70,249 vehicle days. The survey focused on business and commercial traffic, and recorded all passenger and freight trips by passenger cars, as well as lorries with a payload up to 3.5 tonnes. From the survey can be extracted daily mileage, trip length, the length of each pause between trips and the number of trips and pauses (a trip is defined as driving from one destination/activity to the next). Results from the survey are average figures for a year for the vehicle stock. Only days with a trip are included in the analyses. The resulting data include sectors as reported by the respondents, and therefore not necessarily in accordance with the official classification system of sectors in the Motor Register.

This paper examines three broad categories of vehicle. Firstly, we consider passenger cars with commercial owners. The second group is commercial LDVs with up to 3.5 tonnes GVW. The third is lorries with a GVW of up to 12 tonnes. Due to differences in statistical subcategorization, it has been necessary for the analyses of German vehicle mileage to use a special group of LDVs with less than 3.5 tonnes payload. As the payload is around $40 \%$ of the GVW, LDVs with a payload of less than 3.5 tonnes are comparable with LDVs with a GVW of less than 9-10 tonnes. They can therefore be compared with the Danish LDVs of up to 12 tonnes.

\subsection{Data for driving behaviour analyses in section 3.3}

To assess the variation in daily travel distance and the effect of range anxiety, it is necessary to register the daily variation in travel distance over a longer observation period. However, contrary to private passenger cars, including a holiday period is not needed. A high number of vehicles in each company also illustrate the variation.

For Germany, examples of driving patterns were analysed in cooperation with four nursing companies (human health (Q)) by using GPS devices to log daily distances, trip lengths and stop lengths over a period of two to three weeks. The companies' fleets contain between 8 and 22 vehicles. In total more than 1000 vehicle days (the aggregated number of days the vehicles was driven) and more than 8000 trips were recorded.

For Denmark vans or passenger cars from companies in different sectors were followed during periods ranging from a few weeks to half a year: Two companies in the construction sector (F), an electrician and a decorator, and one in the professional service sector (M), a chimney sweeper, were followed for 4-6 months and $2 \frac{1}{2}$ weeks respectively. Two taxi companies (transportation and storage sector $(\mathrm{H})$ ), one with primary basis in central Copenhagen (190 taxis), the other with customers in different towns on Zealand (9 taxis) and two companies in the wholesale and trade sector (G) providing delivery services, one delivering food and groceries to private households in the Copenhagen region (47 LDVs) and the other serving the whole of Denmark (56 18-tonnes trucks) are recorded. The data of four companies were collected by GPS loggers, and the other three's data were supplied by the company's vehicle steering system.

The companies for the German analysis and the three companies from Danish construction (F) and service sectors were chosen because they belong to sectors which in Section 3 are shown to be potentially suitable sectors for a shift to electric vehicles.

The two companies in the wholesale and retail trade sector $(G)$ represent a sector with very broad variation in daily travel distance and therefore a possible relevant company. The taxi companies represent a sector which at the outset is not relevant, but some Danish taxi companies were considering changing to electric drive, especially if they could fast-charge during the day. They are therefore included to complete the analysis.

The overall number of included vehicles and sectors is not at all representative for vehicles potentially suited for a shift to electric drive. They only represent some interesting showcases which can illustrate some of the problems with the shift to electromobility. A reason for this limited choice of companies is the difficulties with finding relevant companies willing to deliver potential information about their customers. Another reason is a limited budget, which did not allow for the cost of distributing GPS trackers to a high number of vehicles.

\section{Results}

The two analysed countries, Denmark and Germany, differ in many aspects. On the one hand, Germany has approximately fifteen times as many inhabitants ( 82 million) as Denmark (5.5 million). On the other, Denmark has a higher GDP level per capita (EUR 
37,000) than Germany's (EUR 29,000). The Danes, however, only have 355 private passenger cars per 1000 inhabitants, whereas the Germans have 543. In both countries the most important economic sector, according to data from Eurostat, is manufacturing (NACE C, GDP per capita EUR 4696 in DK and EUR 5873 in DE). It is followed - in slightly different order - by wholesale and retail trade (NACE G, GDP per capita EUR 4393 in DK and EUR 2757 in DE), real estate activities (NACE L, GDP per capita EUR 3718 in DK and EUR 4492 in DE) and human health (NACE Q GDP per capita EUR 4323 in DK and EUR 2002 in DE).

\subsection{The commercial vehicle stock}

The number of commercial vehicles per inhabitant in Germany is higher than in Denmark (85 versus 75 vehicles/1000 inhabitants, respectively), see Table 1 . Most interesting is that the number of commercial passenger cars per inhabitant in Germany is nearly double the level in Denmark (52 versus 28 vehicles/1000 inhabitants) whereas the number of vans with a GVW up to 3.5 tonnes is more than three times higher in Denmark than in Germany (43 versus 14 vans/1000 inhabitants).

Table 1 furthermore shows that the vast majority (88\%) of the Danish commercial vehicle stock of up to 12 tonnes are vans with a GVW of 3.5 tonnes or less. Thirty-three percent of the vans are registered in the construction sector $(F)$. For all vehicle types, the wholesale and retail sector $(G)$, which includes car dealers, has $23 \%$ (for passenger cars 33\%). The manufacturing (C) and administration and support sectors $(\mathrm{N})$ represent $8 \%$ each. Half of the lorries belongs to construction $(F)$, trade $(G)$ and transportation $(H)$ sectors. For $8 \%$ of the vans and $13 \%$ of the passenger cars, the sector could not be established.

For Germany the most dominant sector is other service activities (S) representing close to one third of the commercial vehicles for all three listed vehicle types. Other sectors with more than $10 \%$ of commercial passenger cars are wholesale and retail trade $(G)$ and manufacturing (C). More than $10 \%$ of vans up to 3.5 tonnes are registered in each of the construction $(\mathrm{F})$, wholesale and retail trade (G) and the manufacturing sectors (C). About 20\% of the lorries between 7.5 and 12 tonnes GVW are registered in transportation and storage $(\mathrm{H})$.

The following analyses take their outsets in the sectors with most vehicles, which are not the same in the two countries as shown.

\subsection{Travel distances of commercial vehicles}

The analyses below will determine the distribution of average daily travel distance separately for passenger cars and LDVs for each economic sector. In Germany it is even possible to figure out the distribution of the average trip length on a specific day. For Denmark it is only possible to calculate an average daily travel distance over a long period, which results in a much lower variance in daily mileage.

\subsubsection{Germany}

For Germany the analyses are made for passenger cars with commercial owners only and for LDVs with up to 3.5 tonnes payload separately. Only vehicles used at the reference date are included, which means that weekends are normally left out of the calculations. The same is the case with holidays for vehicles used by one employee.

Table 2 shows that about $50 \%$ of the passenger cars with commercial owners are driven less than $50 \mathrm{~km}$ and even $71 \%$ are driven less than $100 \mathrm{~km}$ on the surveyed day. The sectors with by far the highest shares of passenger cars with daily mileages below $50 \mathrm{~km}$ and below $100 \mathrm{~km}$ respectively are human health (Q) (67\% are

Table 1

Registered passenger cars, vans and LDVs by economic sectors.

\begin{tabular}{|c|c|c|c|c|c|c|c|c|c|}
\hline \multicolumn{2}{|c|}{ NACE Sector (short) } & \multicolumn{4}{|c|}{ Denmark (end 2010) } & \multicolumn{4}{|c|}{ Germany (end 2011) } \\
\hline & & $\begin{array}{l}\text { Passenger } \\
\text { cars }\end{array}$ & $\begin{array}{l}\text { Vans } \\
0-3.5 \mathrm{t} \\
\text { GVW }\end{array}$ & $\begin{array}{l}\text { Lorries 3.6-12t } \\
\text { GVW }\end{array}$ & $\begin{array}{l}\text { Share of all } \\
\text { vehicles }\end{array}$ & $\begin{array}{l}\text { Passenger } \\
\text { cars }\end{array}$ & $\begin{array}{l}\text { Vans } \\
0-3.5 \mathrm{t} \\
\text { GVW } \\
\end{array}$ & $\begin{array}{l}\text { Lorries 3.6-12t } \\
\text { GVW }\end{array}$ & $\begin{array}{l}\text { Share of all } \\
\text { vehicles }\end{array}$ \\
\hline A & Agriculture & 1939 & 13,720 & 462 & $4 \%$ & 38,563 & 20,248 & 5736 & $10 \%$ \\
\hline B & Mining & 249 & 326 & 14 & $0 \%$ & 7466 & 3622 & 1215 & $0 \%$ \\
\hline $\mathrm{C}$ & Manufacturing & 12,251 & 19,387 & 663 & $8 \%$ & 633,751 & 127,596 & 29,585 & $12 \%$ \\
\hline $\mathrm{D}$ & Electricity, gas & 592 & 2048 & 127 & $1 \%$ & 36,171 & 28,802 & 2124 & $1 \%$ \\
\hline E & Water supply & 259 & 1479 & 301 & $1 \%$ & 24,897 & 17,697 & 5049 & $1 \%$ \\
\hline $\mathrm{F}$ & Construction & 5394 & 80,137 & 1753 & $22 \%$ & 218,417 & 192,374 & 32,607 & $7 \%$ \\
\hline G & Wholesale and retail trade & 47,003 & 41,266 & 1782 & $23 \%$ & 714,316 & 135,557 & 37,762 & $14 \%$ \\
\hline $\mathrm{H}$ & Transportation and storage & 7219 & 9536 & 1185 & $5 \%$ & 150,168 & 84,763 & 34,402 & $6 \%$ \\
\hline I & Accommodation & 1235 & 4498 & 36 & $1 \%$ & 44,138 & 7878 & 692 & $1 \%$ \\
\hline $\mathrm{J}$ & $\begin{array}{l}\text { Information, } \\
\text { communication }\end{array}$ & 6759 & 4079 & 42 & $3 \%$ & 61,509 & 10,125 & 527 & $1 \%$ \\
\hline K & $\begin{array}{l}\text { Financial, insurance } \\
\text { activities }\end{array}$ & 3447 & 1466 & 24 & $1 \%$ & 62,632 & 2195 & 169 & $1 \%$ \\
\hline $\mathrm{L}$ & Real estate activities & 2095 & 5004 & 106 & $2 \%$ & 12,788 & 2610 & 238 & $0 \%$ \\
\hline M & $\begin{array}{l}\text { Professional, scientific } \\
\text { services }\end{array}$ & 6942 & 7817 & 144 & $4 \%$ & 35,182 & 2250 & 150 & $1 \%$ \\
\hline $\mathrm{N}$ & Administrative and support & 12,179 & 19,592 & 617 & $8 \%$ & 411,611 & 79,882 & 27,324 & $7 \%$ \\
\hline $\mathrm{O}$ & Public administration & 2902 & 635 & 57 & $1 \%$ & 128,959 & 44,560 & 13,363 & $4 \%$ \\
\hline $\mathrm{P}$ & Education & 3111 & 1805 & 98 & $1 \%$ & 9529 & 665 & 126 & $0 \%$ \\
\hline Q & Human health & 6876 & 4258 & 126 & $3 \%$ & 175,209 & 10,346 & 1870 & $3 \%$ \\
\hline $\mathrm{R}$ & Arts, entertainment & 692 & 1251 & 52 & $1 \%$ & 19,564 & 2514 & 559 & $0 \%$ \\
\hline S & Other services & 1409 & 2963 & 92 & $1 \%$ & $1,482,264$ & 430,467 & 83,808 & $31 \%$ \\
\hline \multirow[t]{2}{*}{$\mathrm{U}$} & Extraterritorial organisation & - & - & - & - & 6125 & 1030 & 292 & $0 \%$ \\
\hline & Sector not revealed & 18,264 & 19,150 & 1376 & $10 \%$ & & & & \\
\hline \multirow{2}{*}{\multicolumn{2}{|c|}{$\begin{array}{l}\text { Commercial vehicles in all }{ }^{\mathrm{a}} \\
\text { Commercial vehicles per } 1000 \\
\quad \text { inhabitants }\end{array}$}} & 154,743 & 243,912 & 9950 & $100 \%$ & $4,273,259$ & $1,165,077$ & 277,598 & $100 \%$ \\
\hline & & 27.62 & 43.4 & 1.8 & 75.34 & 52.11 & 14.20 & 3.38 & 84.55 \\
\hline
\end{tabular}

${ }^{a}$ From Statistikbanken, possibly including vehicles not actually registered.

Source: Germany - German Federal Motor Transport Authority (KBA). Denmark - Authors' own calculations using data from Statistics Denmark. 
Table 2

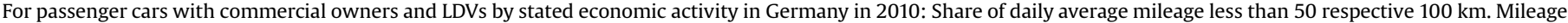
and Trip distribution (see Table 1 for meaning of NACE codes).

\begin{tabular}{|c|c|c|c|c|c|c|c|c|c|c|c|c|}
\hline \multirow{2}{*}{$\begin{array}{l}\text { NACE } \\
\text { Code }\end{array}$} & \multicolumn{6}{|c|}{ Passenger cars with commercial owner } & \multicolumn{6}{|c|}{ LDVs (up to 3.5 tonnes payload) } \\
\hline & $<50 \mathrm{~km}$ & $<100 \mathrm{~km}$ & $\begin{array}{l}\text { Daily mileage } \\
\text { per car }[\mathrm{km}]\end{array}$ & $\begin{array}{l}\text { Mileage } \\
\text { [million } \\
\mathrm{km}]\end{array}$ & $\begin{array}{l}\text { Average no. of } \\
\text { trips/car/day }\end{array}$ & $\begin{array}{l}\text { Average trip } \\
\text { length }[\mathrm{km}]\end{array}$ & $<50 \mathrm{~km}$ & $<100 \mathrm{~km}$ & $\begin{array}{l}\text { Daily mileage } \\
\text { per car }[\mathrm{km}]\end{array}$ & $\begin{array}{l}\text { Mileage } \\
\text { [million } \\
\mathrm{km}]\end{array}$ & $\begin{array}{l}\text { Average no. of } \\
\text { trips/car/day }\end{array}$ & $\begin{array}{l}\text { Average trip } \\
\text { length }[\mathrm{km}]\end{array}$ \\
\hline A & $72 \%$ & $81 \%$ & 79.7 & 674 & 4.9 & 16.4 & $74 \%$ & $92 \%$ & 45.9 & 687 & 8.9 & 5.2 \\
\hline B & $24 \%$ & $37 \%$ & 127.5 & 297 & 5.4 & 22.8 & $53 \%$ & $81 \%$ & 71.4 & 58 & 10.1 & 7.3 \\
\hline C & $49 \%$ & $64 \%$ & 149.7 & 9407 & 3.8 & 39.5 & $50 \%$ & $71 \%$ & 88.0 & 2869 & 7.7 & 11.5 \\
\hline D & $49 \%$ & $81 \%$ & 66.8 & 600 & 6.8 & 9.8 & $57 \%$ & $80 \%$ & 63.4 & 517 & 5.6 & 11.2 \\
\hline E & $38 \%$ & $64 \%$ & 122.1 & 809 & 3.1 & 38.5 & $52 \%$ & $85 \%$ & 60.7 & 502 & 10.7 & 5.7 \\
\hline $\mathrm{F}$ & $56 \%$ & $79 \%$ & 98.0 & 6647 & 3.7 & 26.5 & $59 \%$ & $80 \%$ & 68.0 & 7823 & 4.3 & 15.9 \\
\hline G & $53 \%$ & $69 \%$ & 108.3 & 9837 & 4.4 & 24.4 & $41 \%$ & $65 \%$ & 109.5 & 3933 & 10.1 & 10.8 \\
\hline $\mathrm{H}$ & $42 \%$ & $57 \%$ & 104.2 & 2413 & 11.8 & 8.8 & $36 \%$ & $54 \%$ & 156.5 & 5664 & 43.2 & 3.6 \\
\hline I & $45 \%$ & $76 \%$ & 45.2 & 348 & 4.8 & 9.4 & $63 \%$ & $88 \%$ & 56.3 & 235 & 15.0 & 3.7 \\
\hline $\mathrm{J}$ & $36 \%$ & $72 \%$ & 110.6 & 2114 & 3.0 & 36.4 & $46 \%$ & $71 \%$ & 73.9 & 263 & 16.7 & 4.5 \\
\hline $\mathrm{K}$ & $34 \%$ & $68 \%$ & 103.9 & 1215 & 5.0 & 20.9 & $45 \%$ & $67 \%$ & 67.9 & 28 & 27.1 & 2.5 \\
\hline $\mathrm{L}$ & $59 \%$ & $86 \%$ & 59.5 & 478 & 4.0 & 14.9 & $78 \%$ & $91 \%$ & 37.0 & 138 & 8.0 & 4.6 \\
\hline M & $43 \%$ & $60 \%$ & 135.7 & 3900 & 3.0 & 45.3 & $37 \%$ & $60 \%$ & 112.9 & 603 & 4.7 & 24.1 \\
\hline $\mathrm{N}$ & $34 \%$ & $66 \%$ & 122.4 & 3363 & 5.5 & 22.1 & $51 \%$ & $71 \%$ & 90.8 & 1732 & 7.8 & 11.5 \\
\hline 0 & $48 \%$ & $74 \%$ & 81.1 & 2014 & 10.1 & 8.0 & $69 \%$ & $89 \%$ & 47.7 & 635 & 13.0 & 3.7 \\
\hline $\mathrm{P}$ & $28 \%$ & $35 \%$ & 100.6 & 1011 & 13.1 & 7.7 & $52 \%$ & $78 \%$ & 77.3 & 53 & 14.3 & 5.3 \\
\hline Q & $67 \%$ & $89 \%$ & 62.1 & 4110 & 9.8 & 6.4 & $52 \%$ & $78 \%$ & 75.9 & 390 & 17.4 & 4.3 \\
\hline $\mathrm{R}$ & $55 \%$ & $76 \%$ & 98.2 & 188 & 3.0 & 31.3 & $59 \%$ & $75 \%$ & 104.1 & 95 & 10.2 & 10.6 \\
\hline$S$ & $51 \%$ & $77 \%$ & 122.5 & 3850 & 6.5 & 19.0 & $50 \%$ & $69 \%$ & 97.4 & 1402 & 15.0 & 6.5 \\
\hline $\mathrm{U}$ & $40 \%$ & $47 \%$ & 72.6 & 47 & 2.6 & 23.5 & $28 \%$ & $72 \%$ & 50.5 & 4 & 3.5 & $\mathrm{n} / \mathrm{a}$ \\
\hline Total & $50 \%$ & $71 \%$ & 103.6 & 53,322 & 5.7 & 18.1 & $53 \%$ & $74 \%$ & 85.0 & 27,631 & 11.7 & 7.3 \\
\hline
\end{tabular}

Source: KiD 2010, own calculation

driven less than $50 \mathrm{~km}$ and $89 \%$ are driven less than $100 \mathrm{~km}$ ), agriculture (A) (72\% are driven less than $50 \mathrm{~km}$ and $81 \%$ are driven less than $100 \mathrm{~km}$ ), and real estate (L) (59\% are driven less than $50 \mathrm{~km}$ and $86 \%$ less than $100 \mathrm{~km}$ ).

Fig. 1 and Fig. 2 show the cumulative distribution of the daily mileage per car for selected economic sectors for passenger cars and LDVs under 3.5 tonnes payload respectively. The selected sectors are chosen with respect to their relevance in terms of mileage, vehicle stock, and total mileage (Table 2 ).

For passenger cars Fig. 1 shows a daily driving distance shorter than $50 \mathrm{~km}$ for $50 \%$ or more of the vehicles for the selected sectors with a high number of vehicles. The highest share of vehicles with a daily mileage under the $100 \mathrm{~km}$ threshold is found in human health (Q), other service activities (S), construction and public administration (O), with relatively high shares around $75 \%$ of the cars driving less than $100 \mathrm{~km}$ per day. Transportation $(\mathrm{H})$, manufacturing $(C)$ and, in part, the wholesale and trade sector $(G)$ have a high share of vehicles driving longer than $100 \mathrm{~km}$ per day on average. Even though other service activities (S) has a high share of vehicles driving less than $100 \mathrm{~km}$, the distribution of vehicles driving over $100 \mathrm{~km}$ is more similar to transportation $(\mathrm{H})$ and the wholesale and retail trade sector $(G)$.

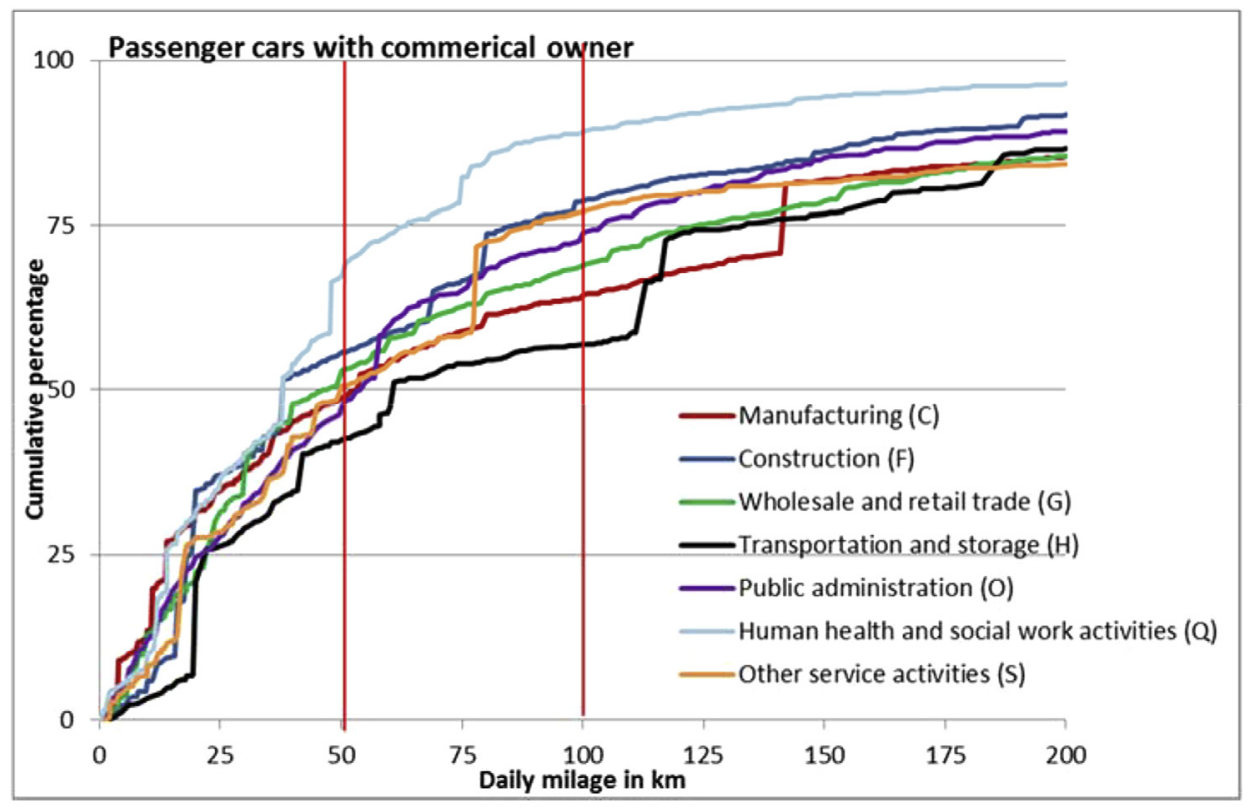

Fig. 1. Cumulative distribution of daily mileage of passenger cars [Source: KiD 2010]. 


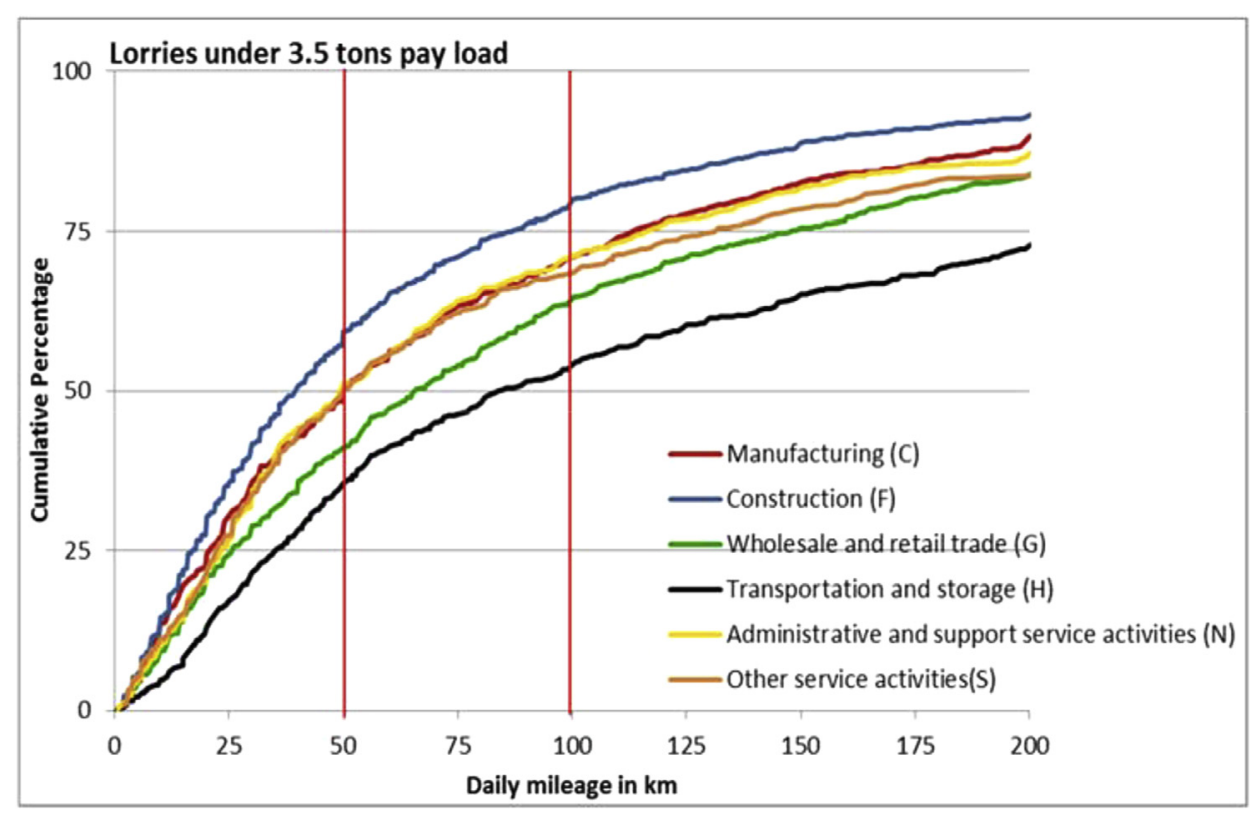

Fig. 2. Cumulative distribution of daily mileage of lorries under 3.5 tonnes payload [Source: KiD 2010].

For LDVs with less than 3.5 tonnes permissible payload, a higher share is driven less than $50 \mathrm{~km}$ (54\%) but a lower share is driven less than $100 \mathrm{~km}$ (76\%) compared to passenger vehicles. As with passenger cars, real estate (L) with $78 \%$, agriculture sector (A) with $74 \%$, and the public administration $(\mathrm{O})$ with $69 \%$ are the sectors with the highest share of vehicles driving less than $50 \mathrm{~km}$ on average daily distances. Only $8-11 \%$ of the LDVs in these sectors are driven more than $100 \mathrm{~km}$ at the actual survey day (see Table 2).

Of the large sectors included in Fig. 1 the Construction sector (F) has the highest share of vehicles driving less than $50 \mathrm{~km}$ as well as $100 \mathrm{~km}$. It is the only sector with more than $75 \%$ of the vehicles driving less than $100 \mathrm{~km}$ per day in average. The graphs for the sectors S, C, and N are nearly identical, with shares around $50 \%$ for vehicles with a daily mileage less than $50 \mathrm{~km}$ and shares around $70 \%$ for vehicles driving less than $100 \mathrm{~km}$ per day. As with the passenger cars in the Other services (S) sector has a higher share of vehicles driving very long daily distances.

The driving pattern of LDVs (under 3.5 tonnes payload) is quite different from the passenger cars'. More trips per day are conducted and as a consequence more stops are made. Trips are generally shorter (Fig. 2). This is especially the case for - again - the Transportation and Storage sector $(\mathrm{H})$ with its strikingly high number of trips per day (43.2) accounting for the highest share of the trips ( $41 \%$ ) but only $20 \%$ of the mileage. The opposite is the case with the Construction sector (F) with average trip lengths of $16 \mathrm{~km} \mathrm{ac}-$ counting for $28 \%$ of the mileage and $13 \%$ of all trips. The sectors S, C, and $\mathrm{N}$ account for about $5 \%$ of the trips and mileage each, except for the Manufacturing sector $(\mathrm{C})$ with overall $10 \%$ of the mileage.

\subsubsection{Denmark}

Due to the methodology of gathering information about travel patterns by reading the odometers the results for Denmark in Table 3 are based on average figures during a period up to four years calculated with 225 working days. The table shows the share of vehicles driving less than 50 and $100 \mathrm{~km}$, respectively, the average travel distance and the number of observations the calculations are based on. For sectors with very few observations figures are excluded. Fig. 3 is furthermore showing a more detailed distribution of travel distances for selected sectors.
Danish commercial passenger cars are driven longer on average (103 km per working day) than commercial vans and lorries (see Table 3). The shares driving less than $50 \mathrm{~km}$ (27\%) and less than $100 \mathrm{~km}(59 \%)$ are both much higher than for vans and lorries. It is opposite to Germany too, where passenger vehicles are driven least. In no sectors (except the small other services (S)) do passenger cars are driven less than the vans in the same sector. Most extreme is transportation $(\mathrm{H})$, in which the average distance is $338 \mathrm{~km}$ and only $12 \%$ of the cars are driven less than $100 \mathrm{~km}$. Of the observations recorded in the sector, 69\% stem from taxis and a further $15 \%$ from other personal transport with e.g. tourists. For these companies it is misleading to calculate distances based on 225 working days, as they are used all year round by several drivers. Instead the daily average is $313 \mathrm{~km}$. Fig. 3 shows a group of sectors in which the passenger cars have more or less the same mileage distribution. Passenger cars in manufacturing $(C)$ are driven more than this middle group. Passenger cars in human health $(\mathrm{Q})$ are driven less.

The group of vehicles for which the sector could not be established has an unclear distribution. Some are driven very little while others are driven very much. It is our assumption that the group consists mainly of the self-employed with no employees so that the car is driven by the owner. The group with a high daily mileage is possibly dominated by self-employed taxi drivers.

The lorries with a GVW of up to 12 tonnes are driven more than the vans. They are mainly driven by professional drivers and a high share probably is driven on more than 225 days so that the share driving less than $100 \mathrm{~km}$ is a little under-estimated. The distribution of daily mileage is quite different across the sectors, with transportation $(\mathrm{H})$ driving most (dominated by goods distribution), followed by wholesale and trade $(G)$, which also includes many lorries distributing goods to shops and private households. Lorries in construction $(\mathrm{F})$, professional service $(\mathrm{M})$ and the small others services sector $(\mathrm{S})$ are driven the least. As with passenger cars, there are two main groups of self-employed vehicle owners, one driving very little and one driving a lot, possibly from the transportation sector $(\mathrm{H})$.

The vans are driven the least. A smaller group of vans with a GVW of under 2 tonnes has a mileage distribution which is not very 
Table 3

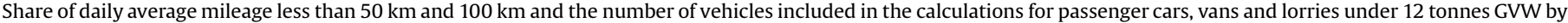
economic activity in Denmark in 2010.

\begin{tabular}{|c|c|c|c|c|c|c|c|c|c|c|c|c|c|}
\hline & & \multicolumn{4}{|c|}{ Passenger cars } & \multicolumn{4}{|c|}{ Vans $0-3.5$ tonnes } & \multicolumn{4}{|c|}{ Lorries 3.6-12 tonnes } \\
\hline & & $<50 \mathrm{~km}$ & $<100 \mathrm{~km}$ & Mean km & Observations & $<50 \mathrm{~km}$ & $<100 \mathrm{~km}$ & Mean km & Observations & $<50 \mathrm{~km}$ & $<100 \mathrm{~km}$ & Mean km & Observations \\
\hline A & Agriculture & \multirow[t]{2}{*}{$26 \%$} & \multirow[t]{2}{*}{$67 \%$} & \multirow[t]{2}{*}{87} & 913 & \multirow[t]{2}{*}{$35 \%$} & \multirow[t]{2}{*}{$81 \%$} & \multirow[t]{2}{*}{71} & 8595 & \multirow[t]{2}{*}{$50 \%$} & \multirow[t]{2}{*}{$85 \%$} & \multirow[t]{2}{*}{62} & 1182 \\
\hline $\mathrm{B}$ & Mining & & & & 20 & & & & 147 & & & & 31 \\
\hline $\mathrm{C}$ & Manufacturing & \multirow[t]{3}{*}{$18 \%$} & \multirow[t]{3}{*}{$52 \%$} & \multirow[t]{3}{*}{108} & 1911 & $38 \%$ & $75 \%$ & 74 & 8000 & $33 \%$ & $58 \%$ & 98 & 1752 \\
\hline $\mathrm{D}$ & Electricity, gas & & & & 42 & $62 \%$ & $90 \%$ & 51 & 719 & $46 \%$ & $88 \%$ & 55 & 328 \\
\hline $\mathrm{E}$ & Water supply & & & & 64 & $46 \%$ & $83 \%$ & 62 & 552 & $25 \%$ & $62 \%$ & 88 & 755 \\
\hline $\mathrm{F}$ & Construction & $23 \%$ & $65 \%$ & 91 & 1382 & $37 \%$ & $81 \%$ & 69 & 34,106 & $43 \%$ & $80 \%$ & 67 & 4712 \\
\hline G & Wholesale, retail trade & $27 \%$ & $71 \%$ & 87 & 5978 & $33 \%$ & $73 \%$ & 79 & 16,364 & $26 \%$ & $52 \%$ & 111 & 4441 \\
\hline $\mathrm{H}$ & Transportation and storage & $6 \%$ & $12 \%$ & 338 & 6347 & $30 \%$ & $63 \%$ & 110 & 3368 & $20 \%$ & $40 \%$ & 165 & 2818 \\
\hline $\mathrm{I}$ & Accommodation & $34 \%$ & $73 \%$ & 81 & 339 & $38 \%$ & $79 \%$ & 71 & 1850 & & & & 65 \\
\hline $\mathrm{J}$ & Information, communication & $24 \%$ & $60 \%$ & 94 & 782 & $36 \%$ & $77 \%$ & 72 & 1160 & $65 \%$ & $78 \%$ & 58 & 113 \\
\hline $\mathrm{K}$ & Financial, insurance activities & $27 \%$ & $75 \%$ & 79 & 460 & $41 \%$ & $78 \%$ & 70 & 533 & & & & 73 \\
\hline $\mathrm{L}$ & Real estate activities & $36 \%$ & $72 \%$ & 81 & 700 & $42 \%$ & $83 \%$ & 65 & 2642 & $53 \%$ & $82 \%$ & 61 & 245 \\
\hline $\mathrm{M}$ & Professional, scientific & $27 \%$ & $68 \%$ & 84 & 1727 & $37 \%$ & $76 \%$ & 74 & 3209 & $50 \%$ & $83 \%$ & 60 & 321 \\
\hline $\mathrm{N}$ & Administrative, support & $21 \%$ & $64 \%$ & 92 & 1444 & $27 \%$ & $71 \%$ & 82 & 7503 & $40 \%$ & $74 \%$ & 82 & 1611 \\
\hline $\mathrm{O}$ & Public administration & $35 \%$ & $79 \%$ & 76 & 1560 & $52 \%$ & $84 \%$ & 60 & 381 & $60 \%$ & $80 \%$ & 98 & 155 \\
\hline $\mathrm{P}$ & Education & $30 \%$ & $58 \%$ & 108 & 1536 & $60 \%$ & $91 \%$ & 51 & 915 & $65 \%$ & $93 \%$ & 41 & 224 \\
\hline Q & Human health & $39 \%$ & $75 \%$ & 74 & 2609 & $54 \%$ & $89 \%$ & 55 & 1939 & $57 \%$ & $90 \%$ & 49 & 348 \\
\hline $\mathrm{R}$ & Arts, entertainment & $33 \%$ & $73 \%$ & 85 & 228 & $40 \%$ & $80 \%$ & 69 & 577 & $67 \%$ & $94 \%$ & 42 & 127 \\
\hline $\mathrm{S}$ & Other services & $41 \%$ & $84 \%$ & 66 & 503 & $35 \%$ & $75 \%$ & 76 & 1224 & $14 \%$ & $33 \%$ & 177 & 254 \\
\hline & Sector not revealed & $34 \%$ & $63 \%$ & 114 & 17,005 & $41 \%$ & $97 \%$ & 66 & 18,491 & $47 \%$ & $63 \%$ & 105 & 4599 \\
\hline & Total & $27 \%$ & $59 \%$ & 103 & 45,550 & $45 \%$ & $80 \%$ & 70 & 112,275 & $38 \%$ & $65 \%$ & 85 & 24,154 \\
\hline
\end{tabular}

Source: Authors' own calculations using Statistics Denmark's Synsdata at the end of 2010 and several sources on sectors

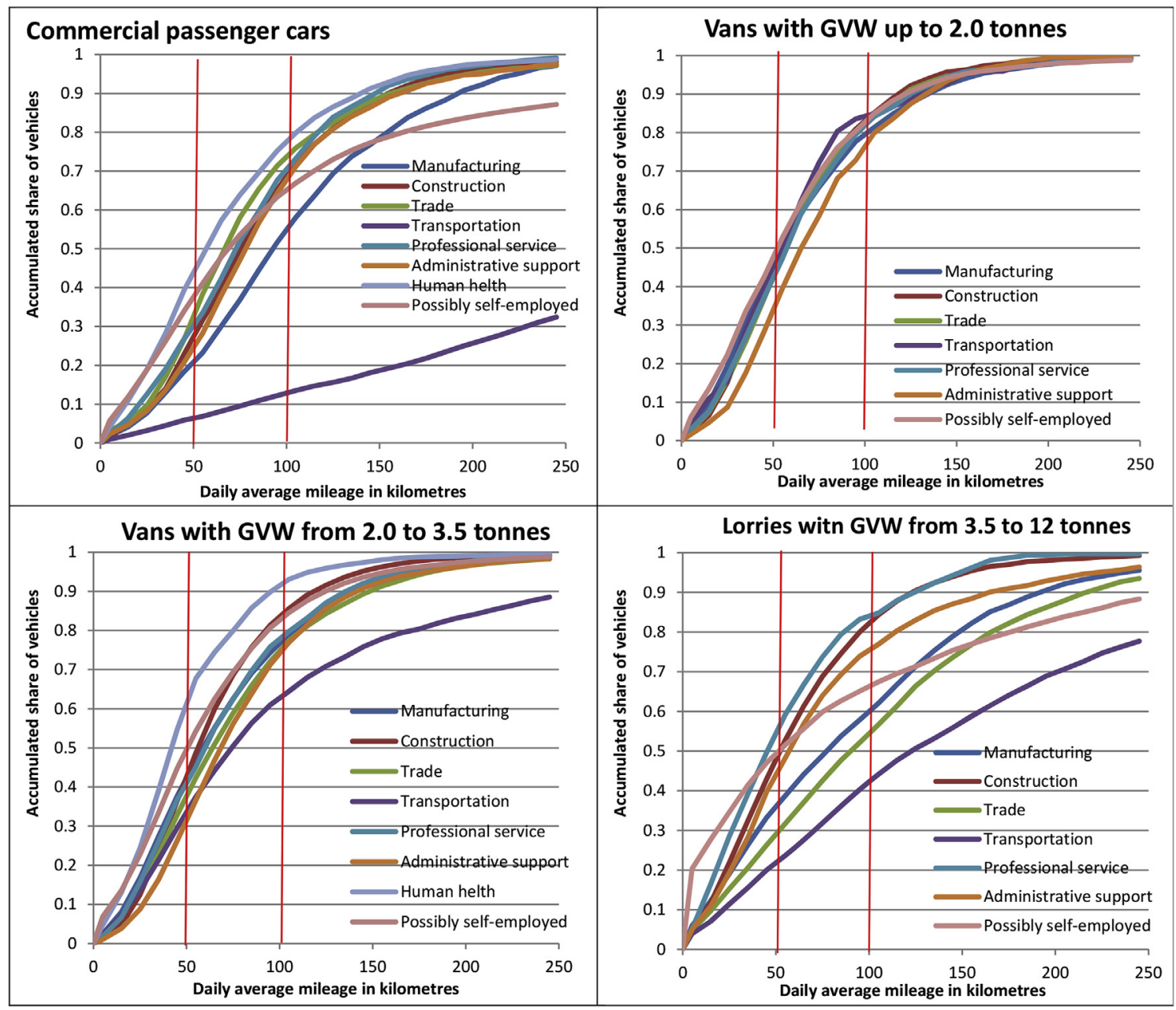

Fig. 3. Accumulated average daily mileage by economic sector for passenger cars and vans of different size, Denmark. 
sector-specific (see also Fig. 3), even small vans in the transportation sector $(\mathrm{H})$ are driven at the average level. The average distribution of small vans is only a little different from larger vans. Of the vans between 2 and 3.5 tonnes, one sector (transportation $(\mathrm{H})$ ) has a higher mileage than average and three groups have a lower average: human health $(\mathrm{Q})$, construction $(\mathrm{F})$ and the selfemployed. Self-employed van owners probably consist of a high share of construction workers running their own businesses with private home renovation and repair. The shortest distances are driven in human health (Q) with 65\% driving less than $50 \mathrm{~km}$ and $90 \%$ driving less than $100 \mathrm{~km}$. Around $37 \%$ of the big vans in construction (F) and $45 \%$ of the self-employed are driven less than $50 \mathrm{~km}$ and more than $80 \%$ are driven less than $100 \mathrm{~km}$.

\subsection{Inter-day variation of travel distances}

Average figures as presented above are not fully useable for the assessment of the fleet's suitability for electric mobility. A shift to an EV is only of interest to a businessman if the car also covers days with longer distances than the average value. It is therefore the maximum mileage during a long period which sets the threshold for the options. This subsection presents results from daily data analyses over a longer period, from some weeks to half a year.

\subsubsection{Germany}

For the four companies in nursing services (human health (Q)), $66 \%$ of all vehicles have not been driven above $100 \mathrm{~km}$ per day during the survey period. The share per company varies between $25 \%$ and $93 \%$ (Table 4 ). The average daily mileage for all vehicles is $47.0 \mathrm{~km}$. Companies 1, 3 and 4 show comparable average daily mileages between 37.6 and $49.1 \mathrm{~km}$. In the fourth company, the vehicles are driven $74.9 \mathrm{~km}$ per day on average. The standard deviation of the daily mileage of the four companies is between 24.7 and $47.1 \mathrm{~km}$.

In Company 1 only one vehicle performed daily mileages longer than $100 \mathrm{~km}$. Of this vehicle's stops, $28 \%$ are longer than $20 \mathrm{~min}$ and only $5 \%$ of the stops are longer than $60 \mathrm{~min}$. Thus only fast charging would be an option to be considered as EV potential. In company 2, six out of eight cars are used for more than $100 \mathrm{~km}$ per day. During the survey period, only three cars from company 3 were used for more than $100 \mathrm{~km}$ in one working day in all. Eight out of 22 cars in company 4 covered more than $100 \mathrm{~km}$ in at least one day during the survey period. Due to stop times mostly below $60 \mathrm{~min}$ a substantial part of the cars would need to charge by a fast charging station. Consequently, our results show significant inter-day variations within the sector.

\subsubsection{Denmark}

Fig. 4 illustrates some results from the two companies in the construction sector $(F)$, represented by two vans smaller than 2.0 tonnes and 12 vans of 3.5 tonnes driving for 4 and 6 months respectively. The two companies are located in the western suburbs of Copenhagen and serve a wide area in the region. On $68 \%$ of the working days of the analysed vans, the mileage is less than $100 \mathrm{~km}$. On average, two of the vehicles are driven more than $100 \mathrm{~km}$ per day, and one close to $100 \mathrm{~km}$. However, all the vans are driven more than $100 \mathrm{~km}$ in at least $10 \%$ of the analysed period, and several are driven longer on half of the days.

In both companies the employees use the van for commuting. Most of the employees live in a radius of $10-20 \mathrm{~km}$ from their company, but two live much further away. Very often the employees drive directly from their home to the customers and most often they do not visit the company address more than a couple of times during the week.

Furthermore, the pauses from work duties are typically too short for charging enough power to overcome the daily mileage if the vehicles were electric.

The above-mentioned chimney sweeper is located in the municipality of Copenhagen and has a licence to serve all houses in a certain area of the municipality. The small vans used by the company are parked at its address overnight. Two vans were followed during two and a half weeks each. The vans were driven $50-60 \mathrm{~km}$ on $40 \%$ of the days, less than that on a further $40 \%$, and more on the remaining few days. Only one car was driven more than $100 \mathrm{~km}$. It happens once when it drove out of the district, probably to collect something from a supplier.

Fig. 5 shows the distribution of the average daily mileage of all vans from different sub-sectors of the construction sector (F), similar to the analysis of all Danish vans in the above section. More than $70 \%$ of the vans owned by the companies in the traditional construction sector are driven less than $100 \mathrm{~km}$ per day, whereas only $15-20 \%$ are driven less than $50 \mathrm{~km}$ in average. The travel pattern of the different sectors' vans seems to be quite similar. Other groups in construction (F), such as building contractors of different kinds, drive a little longer (not shown). These results show that the two detailed analysed companies in construction drive a little longer than similar companies on average, probably due to a location in the Copenhagen region. On the other hand, the chimney sweeper might be more similar to companies serving a certain district for repair, homecare etc.

The taxis' driving behaviour accords well with the rest of the sector as described above (the presented results are referred from the project report SELECT - Suitable Electro Mobility for Commercial Transport). Only in 10-23\% of the days the taxis are driven is the mileage less than $100 \mathrm{~km}$. In $60-75 \%$ of the days the taxis are driven at least $150 \mathrm{~km}$ and in several days more than $500 \mathrm{~km}$. A few taxis - probably owners with no employees - have a daily mileage less than $100 \mathrm{~km}$ most of the days. Only on $7 \%$ of the days would taxis which are driven during the summer period be able to manage without charging during the day (calculated in accordance with the principles described in (Fetene et al., 2015)). The company driving during the winter period has no days where it would be able to manage without charging during the day.

For the nation-wide delivery service, only $7 \%$ of the vehicle-days are shorter than $100 \mathrm{~km}$. On $83 \%$ of the days the trucks are driven more than $150 \mathrm{~km}$, and on $25 \%$ even more than $500 \mathrm{~km}$. The other delivery company drives less. However, this company lease their lorries from a transport company so that they can deliver in the morning. The rest of the days the lorries are probably used by others. But even in 'their' part of the vehicle-day, $1 / 3$ of the lorries are driven more than $100 \mathrm{~km}$. Only the company with the short delivering period would manage without charging during the day

Table 4

Company - Number of vehicles - average daily mileage - variance - share of vehicles driving less than $100 \mathrm{~km}$ in all analysed days.

\begin{tabular}{|c|c|c|c|c|}
\hline Company & No. of vehicles & Average daily mileage $[\mathrm{km} / \mathrm{day}]$ & Standard deviation & Share of vehicles below $100 \mathrm{~km} \mathrm{[ \% ]}$ \\
\hline 1 & 15 & 37.6 & 35.7 & 93.3 \\
\hline 2 & 8 & 74.9 & 24.7 & 25.0 \\
\hline 3 & 8 & 49.1 & 47.1 & 62.5 \\
\hline 4 & 22 & 42.5 & 31.2 & 63.6 \\
\hline All companies & 53 & 47.0 & 33.9 & 66.0 \\
\hline
\end{tabular}




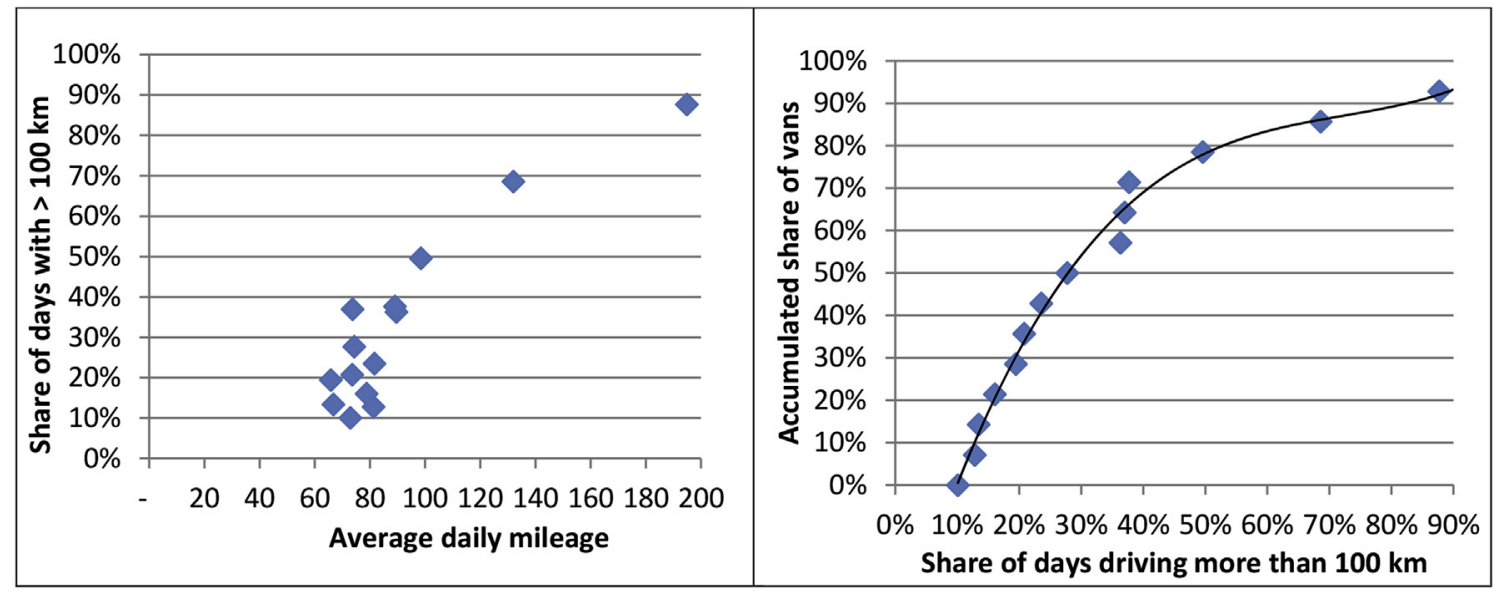

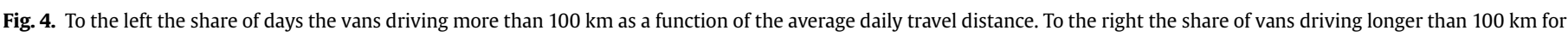
a given share of the analysed period.

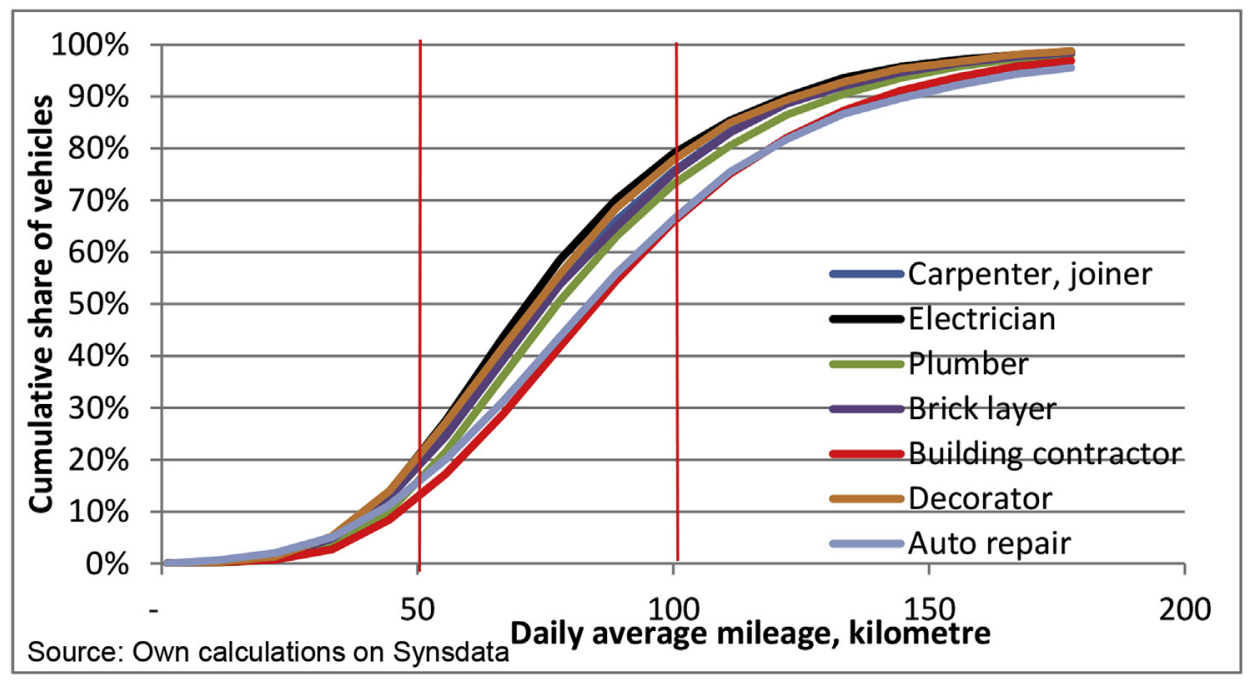

Fig. 5. Daily mileage of vans by different professional groups in Denmark.

with a shift to EVs.

\section{Discussion}

In this section we will assess the empirical results related to the suitability of commercial vehicles in different target groups to shift to electric mobility. We point to important barriers and discuss possible policies to overcome these.

\subsection{Results from the analyses}

In terms of size of vehicle stock, overall mileage and average daily travel distances, vans in construction (F) and passenger cars in human health $(\mathrm{Q})$ are most suitable for a shift to electric mobility in both countries. For Denmark the vans from human health $(\mathrm{Q})$ might be relevant too. For Germany both passenger cars and LDVs with a payload of up to 3.5 tonnes in construction $(F)$ seem to be suitable for shifting to EVs. The same is the case with a share of vehicles in other services (S). This sector is very small in Denmark, but the few cars used by the sector are driven less than others.

In Denmark commercial passenger cars - except for the groups mentioned above and a smaller share owned by self-employed without employees - are driven very far and only a few are suitable for electric mobility. Lorries over 3.5 tonnes GVW are not suitable either.

Vans and small lorries in administrative and support service activities (N) and manufacturing (C) seem to be particularly relevant to shift to EV's in Germany too. For Denmark a small share of the vans in these sectors and in professional services $(\mathrm{M})$ might be relevant, but it is necessary to carry out a more detailed study.

When only considering the average daily mileage, at least half of the German commercial vehicles in the mentioned sectors, and probably closer to $2 / 3$, can be shifted to EVs, since at least half of them are driven less than $50 \mathrm{~km}$ and more than $70 \%$ are driven less than $100 \mathrm{~km}$ a day. In Denmark a slightly smaller share of vans in the chosen sectors in driven less than $50 \mathrm{~km}$ per day. It might therefore be a lower share of Danish vans that can be replaced by EVs.

When including the inter-day variation in the daily mileage, the share which could be replaced is substantially lower. In most of the companies in Denmark and Germany, many cars exceed the current travel range of EVs - at least on some days during the analysed 
period. Indeed, the analyses are far from being representative for the part of the commercial sectors which are shown to be relevant for electric mobility. Consequently, the share of the vehicles which can be replaced by an EV cannot be stated but it is clearly lower that than the above-mentioned shares.

Transportation and storage $(\mathrm{H})$ is the least suitable sector, especially for Denmark. The analysis in Section 3.3.2 shows that, even when considering fast charging between trips, it might be difficult to overcome the travel range problems with the electric vehicles currently available on the market. However, due to the objective of the European Commission to have emission-free city logistics in major urban centres by 2030, new concepts for parcel distribution (e.g. urban micro consolidation centres) and new electric vehicle concepts must be developed. The development has started with pilot projects by DHL and UPS using EVs for last mile parcel distribution and PostDanmark testing EVs for mail delivery (Ingeniøren, 2013). Recently DHL took over Streetscooter, a company specialized in electrified vans for parcel companies, and now produce cars for themselves.

The German wholesale and retail trade sector $(G)$, which has the second highest number of registered vehicles, the highest share of total mileage and approximately $70 \%$ of cars driving less than $100 \mathrm{~km}$ per day might be relevant for electric mobility, too. However, the sector is very complex, which blurs the picture. A very high share of new registrations, especially of passenger cars (more than $90 \%$ in Germany and a third of this in Denmark (authors' own calculations based on data in the annual version of the motor register), indicates that automobile dealers represent a substantial part of the vehicles in the stock, only keeping the cars until they are passed on to the customers. An unknown share of the companies have a driving behaviour similar to that of the transportation sector $(\mathrm{H})$, as can be seen with the example of the two food delivery companies in Section 3.3.2. Due to this, the suitability of the sector cannot be assessed but it is probably only a very small share.

The strength of the three-step methodology used here is that it is possible to point to sectors with a big potential for electric drive for each vehicle type. On the other hand, the weakness of the analyses of statistical data is that it does not show the daily variation in travel distances. This is well known for passenger cars (Christensen, 2011; Greaves et al., 2014) and confirmed by the analyses in Section 3.3 for the commercial fleet too. The main difference seems to be between vehicles only driving in a predefined area or fixed daily routes and vehicles serving a large area with more random customers. The information based on average travel distances collected over one or more years, as in the Danish case and during only 1 day as in the German case, does not reveal the variation in companies' behaviour. The analyses in Section 3.3 are not representative enough to indicate the size of the problem on a national scale.

\subsection{Technical issues of importance for the deployment of commercial EVs}

The current low deployment of EVs in general and in the commercial sector especially (see Section 1.1) might be due to both economic and practical reasons.

To overcome the problem with the daily variation in travel distance it might be a possibility to keep a few conventional cars in the fleet that can be used for extra-long trips. For vans serving a certain district, such as the chimney sweepers', and not being used for commuting it might be possible to organise which routes should be served by the EVs and which by a conventional car in case of a mixed fleet. For this purpose, a fleet managing system to optimise or at least organise the distribution of daily mileage on the vehicles in the fleet might be useful. This question is analysed in other parts of the SELECT project (Suitable Electro Mobility for Commercial Transport).

Another option is to recharge the EVs during the day, either with a fast-charging facility en route - since the majority of the stops are too short to recharge a substantial portion with a slow-charging facility - or by the customer during the course of their work, either on the customers' private premises or at a public charger close by them. None of the available options are optimal. Charging en route takes time from work and might only be an option during e.g. a lunch break. Only with a very dense charging network would charging close to the customer be an option, and is therefore only relevant in dense city areas and in areas with dedicated charging poles. This is particularly a problem for the taxi companies, who have very long daily mileages. Charging at the location of the customers might be difficult in relation to billing in case of private households and small companies and an agreement needs to be made with the customer. At construction sites it might be included in a tender and therefore easier to handle.

Another technical restriction for commercial transport is the higher weight of the vehicles due to the battery weight. This additional weight can reduce the payload by 200-400 kilos. Especially vans with a GVW close to 3.5 tonnes are remarkably affected by the reduced payload. The advantage of these vans is that they can be driven with an ordinary passenger car licence (licence type B). For heavier vehicles a special truck driving licence is needed. In the construction sector $(\mathrm{H})$ some vehicles are used to carry very heavy materials (e.g. by masons) for which the payload is of significant importance. Others bring heavy tools or an entire workshop including heavy material (e.g. plumbers). However, most often the payload of the van is of minor importance. Especially in the parcel distribution sector most parcels are lightweight (e.g. $1-5 \mathrm{~kg}$ ). Instead the volume of the car is of importance, resulting again in a van at 3.5 tonnes GVW. If batteries are added to the car, it cannot be driven with a type $B$ licence. These big vans will therefore suffer from limited battery capacity and thereby shorter travel range than what is of interest to companies.

Since the beginning of 2015 a change in the German driving licence regulation allows persons with a driving licence class $B$ to drive electric vans with GVW up to 4.25 tonnes (see Bundesministerium für Verkehr und digitale Infrastruktur, 2014). This initiative might be an important support to the use of electric vans in companies for which either weight or size of the van is of importance, because it makes it possible to add heavy batteries to the big vans close to 3.5 tonnes GVW and thereby increase the travel range. The new German rule is too new to evaluate if the change has attracted more companies to buy EVs.

\subsection{The influence of economy and tax policy}

The results of the analyses show substantial differences between Denmark and Germany in both the composition and the mileage of the car fleet. The differences in mileage are found for all sectors and for both commercial passenger cars and vans. We assess these differences mainly to be due to a very different structure of vehicle taxation. Danish passenger cars are 2-3 times more expensive than German ones due to high purchase tax and VAT.

Vans are subject to a lower purchase tax in Denmark compared to passenger cars. However, if the backseats are removed from passenger cars and a few other smaller adjustments are made, the car is considered a van with a lower purchase tax and a small annual fee for the allowance to drive privately too (Skatteministeriet, 2015d).

Furthermore, the rules for taxation of company passenger cars used by employees are not very favourable for the choice of EVs. The company is allowed to pay all maintenance and running cost 
for the employee, but, for the user of the company car, $25 \%$ of the value of the car up to EUR 40,000 and $20 \%$ of the remaining value is treated as taxable income (Skatteministeriet, 2015a). On top of this, since 2010 an environmental fee has been added with the purpose of making it attractive to choose a low emission car. It is therefore often more attractive for employees who drive an average daily mileage for the company to use his/her own car and get a tax free rebate per documented kilometre for business trips, because this rebate equals the marginal cost of owning and using a small family car. In Germany a monthly rate of $1 \%$ of the value of a company car is treated as taxable income for private use of a free company car, which equals only $12 \%$ of the value annually. An effect of the rules is, as shown in Section 3.2.2, that commercial passenger cars in Denmark is the type of commercial vehicles with the highest daily average mileage. In Germany commercial passenger cars are driven less than vans.

The result of the generally extensive use of commercial passenger cars in Denmark is that they are most often not suitable for being replaced by electric vehicles. In cases where the company car is neither used for representative purposes nor privately, the company will often choose a van instead of the passenger car. Their use might rather be comparable with the passenger cars in Germany and therefore, a potentially attractive group for electric mobility in Denmark in line with the German passenger cars. This is probably the reason why small vans have the same mileage distribution, independent of the sector.

Another taxation rule of importance for the differences between the two countries is that employees who have a company van with a special adaptation (e.g. stalls for materials and tools) are allowed to use the van for their commuting trips without paying companycar tax for this (Skatteministeriet, 2015b). If they use it for further private transport, they have to pay a minor tax for the extra kilometres. The result is, as the example in Section 3.3.2 shows, that the construction workers and other engineers with changing customers from day to day often use the van for commuting instead of leaving it at the office/workshop. The result is that some of these vans have a high daily mileage and are therefore not suitable for electric mobility unless the companies' policies on the use of the vehicles are changed or legislation prevents the use for private commuting. The share of suitable vans is thus lower in Denmark than in Germany.

An analysis based on more than 2000 interviews with a representative sample of company owners in the two countries (and Austria) shows that the Danish owners are less willing to introducing EVs in their vehicle fleets than the Germans (and Austrians). The described difference between the taxation structure and the resulting behaviour in the two countries might be a part of the explanation of the different attitudes (Kaplan et al., 2016).

A Danish calculator of total cost of ownership (TCO) has been developed to help people and companies assess if their travel pattern is attractive for shifting to an EV. By using the calculator it can be shown than an EV as the Nissan eV200 is approximately EUR 6500 more expensive than a similar ICE van when considering Danish registration taxes (without taxes and VAT, the EV is approximately EUR 11,600 more expensive). In the case of leasing, the TCO is EUR 0.06 to EUR 0.15 higher per km by average use of the vehicles, ranging from 5 to $15,000 \mathrm{~km}$ per year. However, although the purchase price is higher, the TCO per kilometre decline when the EV is used more, since travel costs are lower than for conventional vehicles. Also, driving in urban conditions will favour EVs, since the energy use for conventional vehicles is relatively higher at lower speeds. Overall a shift to electric mobility might be economically more or less equal in big cities when considering the full costs. But, especially in the big cities, the driving pattern might be less attractive due to a dispersed localisation of customers and businesspeople. The paradox is therefore that, in situations where the electric vehicle should be economically attractive, the practical driving behaviour is a limitation instead.

\section{Conclusions}

The resulting overall mileage and variation of daily mileage showed that, for both countries, the construction sector $(F)$, human health $(\mathrm{Q})$ and other services $(\mathrm{S})$ are suitable for the use of electric vehicles given the present technological state of the art. Manufacturing (C) and professional services (M) show a possible relevance regarding vehicle stock and suitability too in Germany. For Germany no significant difference between the use of passenger cars and LDVs could be shown and both kinds of cars are relevant. In Denmark only vans are suitable as EVs because a high share of the commercially used passenger cars and LDVs exceed driving ranges of available EVs. An exemption from this is human health (Q). The differences in the size of the commercial vehicle fleet and mileage for different types of cars between the two countries are explained mainly by differences in vehicle taxation of passenger cars compared to vans without backseats. Danish tax regulation is quite unique and consequently the results for passenger cars for Germany are the most applicable for other countries.

The analysis of the travel patterns of vehicles by GPS tracking in both construction (F) in Denmark and in nursing services (human health $(Q)$ ) in Germany showed significant inter-day variations in travel distances, resulting in a share of days where the travel range is exceeded. Thus the share of vehicles which could be replaced by electric vehicles is lower than the statistical results predicted. On the other hand, companies which serve a defined small area and/or have fixed daily routes could easily shift their fleet to EVs. Most of them would possibly need a few conventional cars to cover trips which exceed electric driving ranges. Companies with huge catchment areas are less suitable for the use of EVs.

The results regarding the transportation sector $(\mathrm{H})$ are ambiguous: A high share of companies travel long daily distances, as confirmed by the analysis of Danish taxis and food distribution companies. Therefore, most of this sector is not suitable for electric mobility and fast charging will probably not solve the problem. On the other hand, the vans of some parcel distribution companies exhibit daily mileages mainly not exceeding electric driving ranges and several companies have started to experiment with EVs.

The analyses reveal that the share of vans suitable for transition in Denmark is lower than for Germany too. This is due to a Danish right for construction workers and entrepreneurs to commute with the company car without paying tax for a company car. When analysing commercial driving patterns in other countries, one should be aware of the consequences of a similar rule.

This paper suggests other countries should consider changing their driving licence regulations so that electric LDVs with a GVW up to 4.25 tonnes can be driven by "type B" driving-licence holders, as has been done in Germany. If this rule were adapted by many EU countries, the car manufacturers might be take a greater interest in a market for large electric vans with battery packs of up to $500-700 \mathrm{~kg}$. This could lead to a greater supply of different models with higher performance. However, the paradox of a van which can be driven the necessary kilometres possibly costing so much that the kilometre price is on a par with conventional vans might still be relevant.

\section{Acknowledgements}

The study is a part of the project "SELECT - Suitable Electro Mobility for Commercial Transport", one of the projects financed by the ERA-NET Plus scheme Electromobility+. The scheme was co- 
funded by the European Commission and national funding authorities in Austria, Denmark and Germany as part of the 7th EU Framework Programme under Grant Agreement No. 287143.

The authors want to thank three unknown reviewers for constructive comments to a former version of the paper.

\section{References}

Bae, S. H., Sarkis, J., \& Yoo, C. S. (2011). Greening transportation fleets: Insights from a two-stage game theoretic model. Transportation Research E: Logistics and Transportation Review, 47, 793-807.

Barfod, M. B., Kaplan, S., Frenzel, I., \& Klauenberg, J. (2016). COPE-SMARTER - a decision support system for analysing the challenges, opportunities and policy initiatives: A case study of electric commercial vehicles market diffusion in Denmark. Research in Transportation Economics, 55, 3-11.

Bühler, F., Franke, T., \& Krems, J. F. (2011). Usage patterns of electric vehicles as a reliable indicator for acceptance? Findings from a German field study. In Transportation research board 90th annual meeting (No. 11-0227).

Bundesministerium für Verkehr und digitale Infrastruktur. (2014). Vierte Verordnung über Ausnahmen von den Vorschriften der Fahrerlaubnis-Verordnung [Fourth Ordinance on exemptions from the provisions of the driving licence directive]. http://www.bgbl.de/xaver/bgbl/start.xav?startbk=Bundesanzeiger BGBl\&jumpTo=bgbl114s2432.pdf. (Accessed 31 October 2016).

Bundesministerium für Wirtschaft und Energie. (2009). Deutschland soll Leitmarkt für Elektromobilität werden [Germany is to be leading market for electric mobility]. https://www.bmwi.de/DE/Presse/pressemitteilungen,did=309868.html.

(Accessed 31 October 2016).

Christensen, L. (2011). Electric vehicles and the costumers. Report WP 1.3 version 0.1, EDISON project http://www.edison-net.dk/Dissemination/Reports/Report_011. aspx. (Accessed 31 October 2016).

COMPETT Team. (2015). Competitive electric town transport. Guidelines to increased use of electric vehicles. COMPETT June 2015. Institute of transport economics, Austrian energy agency, Danish road directorate. Vienna University of Technology.

COWI. (2014). EL-Bilers potentialer i serviceerhverv [EVs Potentials in Service Sector]. http://docplayer.dk/3507237-El-bilers-potentialer-i-serviceerhverv.html. (Accessed 31 October 2016).

Dansk Elbil Alliance. (2015). Bestand af elbiler i Danmark [Stock of Electric vehicles in Denmark]. http://www.danskelbilalliance.dk/Statistik/Bestand_modeller.aspx. (Accessed 31 October 2016).

Deutscher Bundestag. (2014), Gesetz zur Bevorrechtigung der Verwendung elektrisch betriebener Fahrzeuge, Elektromobilitätsgesetz vom 5. Juni 2015 (Act to preempt the use of electric vehicles, electromobility law) (BGBI. I S. 898).

Die Bundesregierung. (2009). Nationaler Entwicklungsplan Elektromobilität der Bundesregierung [National Electromobility Development Plan of the Federal Government]. Berlin.

Die Bundesregierung. (2016). Einigung auf Kaufprämie für E-Autos [Agreement on buyer's premium for electric vehicles]. https://www.bundesregierung de/ Content/DE/Artikel/2016/04/2016-04-27-foerderung-fuer-elektroautos-beschlossen.html. (Accessed 31 October 2016).

Dudenhöffer, F., Bussmann, L., \& Dudenhöffer, K. (2012). Elektromobilität braucht intelligente Förderung [Electromobility needs intelligent promotion]. Wirtschaftsdienst, 92(4), 274-279.

Duke, M., Andrews, D., \& Anderson, T. (2009). The feasibility of long range battery electric cars in New Zealand. Energy Policy, 37, 3455-3462.

Energistyrelsen. (2015a). Elbiler [Electric vehicles]. https://ens.dk/sites/ens.dk/files/ Transport/elbiler_arkiveret_indhold.zip, see 1 Ebiler_Energistyrelsen.pdf, 11.11.2016.

Energistyrelsen. (2015b). Elbiler [Electric vehicles]. https://ens.dk/sites/ens.dk/files/ Transport/elbiler_arkiveret_indhold.zip, see 1 Ebiler og 1.5.3.24 Elbilers energiforbrug_Energistyrelsen.pdf, 11.11.2016.

European Commission. (2015). Statistical classification of economic activities in the european community. Rev, 2(2008). http://ec.europa.eu/eurostat/ramon/ nomenclatures/index.cfm?TargetUrl=LST_NOM_DTL\&StrNom=NACE_REV2. (Accessed 31 October 2016)

Evans, G., \& Azmin-Fouladi, N. (2005). Accessibility and user needs in transport design. In Proceedings of Include 2005. London: International Conference on Inclusive Design, Helen Hamlyn Research Centre, Royal College of Art.

Feng, W., \& Figliozzi, M. (2013). An economic and technological analysis of the key factors affecting the competitiveness of electric commercial vehicles: A case study from the USA market. Transportation Research Part C: Emerging Technologies, 26, 135-145.

Fetene, G. M., Prato, C. P., Kaplan, S., Mabit, S. L., \& Jensen, A. F. (2015). Harnessing big-data for estimating the energy consumption and driving range of electric. In Transportation research board (TRB) 95th annual meeting.

Figenbaum, E., Fearnley, N., Pfaffenbichler, P., Hjorthol, R., Emmerling, B., Jellinek, R., et al. (2015). Increasing the competitiveness of e-vehicles in Europe. European Transport Research Review, 7(3), 1-14.

Franke, T., Bühler, F., Cocron, P., Neumann, I., \& Krems, J. F. (2012). Enhancing sustainability of electric vehicles: A field study approach to understanding user acceptance and behavior. In M. Sullman, \& L. Dorn (Eds.), Advances in traffic psychology (pp. 295-306).
Globisch, J., Schneider, U., \& Dütschke, E. (2013). Acceptance of electric vehicles by commercial users in the electric mobility pilot regions in Germany. In Eceee Summer Study proceedings (Vol. 12, pp. 973-983). Stockholm: eceee.

Gnann, T., Plötz, P., Kühn, A., \& Wietschel, M. (2015). Modelling market diffusion of electric vehicles with real world driving data-German market and policy options. Transportation Research a: Policy and Practice, 77, 95-112.

Greaves, S., Backman, H., \& Ellison, A. B. (2014). An empirical assessment of the feasibility of battery electric vehicles for day-to-day driving. Transportation Research Part a: Policy and Practice, 66, 226-237. http://dx.doi.org/10.1016 j.tra.2014.05.011.

Green eMotion Team. (2015). Green eMotion project results. http://www. greenemotion-project.eu/upload/pdf/deliverables/Project-Results-online.pdf. (Accessed 31 October 2016).

Hackbarth, A., Lunz, B., Madlener, R., Sauer, D. U., \& De Doncker, R. W. (2010). Plug-in hybrid electric vehicles for CO2-free mobility and active storage systems for the grid, part I. E. ON ERC Series ISSN, 7415.

Hanke, C., Hülsmann, M., \& Fornahl, D. (2014). Socio-economic aspects of electric vehicles: A literature review. In M. Hülsmann, \& D. Fornahl (Eds.), Evolutionary paths towards the mobility patterns of the future (pp. 13-36). Berlin, Heidelberg: Springer.

Hebes, P., Menge, J., \& Lenz, L. (2010). Service Traffic. An entrepreneurial view on travel behaviour, 12th WCTR, July 11-15, 2010 - Lisbon, Portugal.

Holtsmark, B., \& Skonhoft, A. (2014). The Norwegian support and subsidy policy of electric cars. Should it be adopted by other countries? Environmental Science \& Policy, 42, 160-168.

Hoogma, R. (2002). Experimenting for sustainable transport: The approach of strategic niche management. Taylor \& Francis.

Ingeniøren. (2013). Post Danmark udvider med elbiler $i$ hele landet [Post Denmark expands with electric cars inC the country]. http://ing.dk/artikel/post-danmarkudvider-med-elbiler-i-hele-landet-136055. (Accessed 31 October 2016).

Kaplan, S., Gruber, J., Reinthaler, M., \& Klauenberg, J. (2016). Intentions to introduce electric vehicles in the commercial sector: A model based on the theory of planned behaviour. Research in Transportation Economics, 55, 12-19.

Kasten, P., Zimmer, W., \& Leppler, S. (2011). CO2-Minderungspotenziale durch den Einsatz von elektrischen Fahrzeugen in Dienstwagenflotten [CO2 reduction potential through the use of electric vehicles in company car fleets]. https://www. oeko.de/oekodoc/1343/2011-027-de.pdf. (Accessed 31 October 2016).

Kemp, R., Truffer, B., \& Harms, S. (2000). Strategic niche management for sustainable mobility. In K. Rennings, O. Hohmeyer, \& R. L. Ottinger (Eds.), Social costs and sustainable mobility (pp. 167-187). Heidelberg: Physica-Verlag.

Kreiner, D., Maringer, A., \& Zechner, L. (2011). ECONNECT-improving connectivity in the alps implementation in the pilot region northern limestone alps. Eco.Mont-Journal on Protected Mountain Areas Research, 4, 41-46.

Mock, P., \& Yang, Z. (2014). Driving electrification. Washington: The International Council on Clean Transportation (ICCT).

Reiner, R., Cartalos, O., Evrigenis, A., \& Viljamaa, K. (2010). Challenges for a European market for electric vehicles. European Parliament.

Schuller, A., \& Hoeffer, J. (2014). Assessing the impact of EV mobility patterns on renewable energy oriented charging strategies. Energy Procedia, 46, 32-39.

Scott, M., Hopkins, D., \& Stephenson, J. (2014). Understanding Sustainable mobility: The potential of electric vehicles. In 2014 IEEE 15th international conference on mobile data management (Vol. 2, pp. 27-30). IEEE.

Skatteministeriet. (2015a). Skat af fri bil [Taxation of free company car]. http://www. skat.dk/SKAT.aspx?oId=1789830. (Accessed 31 October 2016).

Skatteministeriet. (2015b). Særlige køretøjer [Vehicles for special use or adaptation]. https://www.skat.dk/SKAT.aspx?old=1947975. (Accessed 31 October 2016).

Skatteministeriet. (2015c). Aftale mellem regeringen (V) og Socialdemokratiet, Dansk Folkeparti og Radikale Venstre om de fremtidige afgiftsvilkår for elbiler og brændselscellebiler [Agreement between the Government and 3 other parties about future taxis for electric vehicles and fuel cell vehicles]. http://www.skm.dk/media/ 1265173/091015_aftaletekst_elbiler.pdf. (Accessed 31 October 2016).

Skatteministeriet. (2015d). Registreringsafgift [Purchase tax]. http://www.skat.dk/ SKAT.aspx?oId=1817284. (Accessed 31 October 2016).

Sun, X.-H., Yamamoto, T., \& Morikawa, T. (2015). Stochastic frontier analysis of excess access to mid-trip battery electric vehicle fast charging. Transportation Research D Transport and Environment, 34, 83-94.

Trommer, S., Jarass, J., \& Kolarova, V. (2015). Early adopters of electric vehicles in Germany unveiled. In Proceedings of the 28th international electric vehicle symposium and exhibition.

Van Duin, J. H. R., Tavasszy, L. A., \& Quak, H. J. (2013). Towards e(lectric)-urban freight: First promising steps in the electronic vehicle revolution. European Transport-trasporti Europei, 54, 2013.

Wermuth, M., Neef, C., Hautzinger, H., Lenz, B., \& Heinzmann, H.-J. (2012). Kraftfahrzeugverkehr in deutschland 2010 [Motor vehicle traffic in Germany 2010]. Braunschweig: Research project commissioned by the Federal Ministry of Transport. Building and Urban Development - FE-Nr. 70.801/2006.

Wikström, M. (2015). Electric vehicles in action. Doctoral dissertation. KTH Royal Institute of Technology.

Wikström, M., Hansson, L., \& Alvfors, P. (2014). Socio-technical experiences from electric vehicle utilisation in commercial fleets. Applied Energy, 123, 82-93.

Wikström, M., Hansson, L., \& Alvfors, P. (2015). An end has a start - investigating the usage of electric vehicles in commercial fleets. Energy Procedia, 75 1932-1937. 